\title{
Effects of Elevated Glucose Concentrations on
}

\section{the Metabolism of the Aortic Wall}

\author{
Anthony D. Morrison, Rex S. Clements, Jr., and Albert I. Winegrad \\ From the George S. Cox Medical Research Institute, Department of Medicine, \\ University of Pennsylvania School of Medicine, \\ Philadelphia, Pennsylvania 19104
}

A B S T R A C T The effects of elevated glucose concentrations on the metabolism of the aortic wall were examined in a preparation of tubular segments of rabbit descending thoracic aorta comprised of intima and media only. Increased medium glucose concentrations (20-50 $\mathrm{mm}$ ) resulted in increased aortic sorbitol and fructose concentrations and an increased rate of fructose release into the medium. This increased flux through the polyol pathway can be explained as a consequence both of an increased free intracellular glucose concentration and of the kinetic characteristics of the alditol: NADP oxidoreductase and the L-iditol: NAD oxidoreductase isolated and partially purified from rabbit thoracic aorta. Incubation with elevated glucose concentrations for 2 or more hr was also associated with a significant increase in the water content of the tissue without a significant increase in the inulin space. The oxygen uptake of the tissues incubated with elevated glucose concentrations was significantly reduced; this appears to result from a limitation imposed by oxygen diffusion at physiological oxygen tensions. A compensatory increase in glycolysis and an increase in the aortic lactate/pyruvate concentration ratio were also observed. The oxygen uptake and lactate production of tissue incubated with $50 \mathrm{~mm}$ glucose could be preserved at rates observed in tissue incubated with a physiological glucose concentration by the addition of $40 \mathrm{~mm}$ mannitol to the medium. Aortic intima and media from alloxan-diabetic rabbits also exhibit an increased water content and a decreased rate of oxygen uptake. These observations suggest that elevated ambient glucose concentrations result in significant alterations in the metab)olism of aortic intima and media.

Dr. Winegrad is the recipient of Research Career Development Award GM06405 from the National Institute of General Medical Studies.

Received for publication 27 Junc 1972 and in roised form 8 August 1972.

\section{INTRODUCTION}

The possibility that hyperglycemia produces derangements in the metabolism of the arterial wall which might potentiate the effects of other genetic and environmental factors that contribute to the development of arterial disease has not received serious consideration. The studies that form the basis of this report suggest that an elevated ambient glucose concentration results in significant alterations in glucose metabolism, water content, and respiration in the intima and media of rabbit thoracic aorta.

The immediate stimulus to these studies was the observation that the polyol pathway of glucose metabolism is operative in the aortic wall (1). This pathway catalyzes the reduction of $\mathrm{D}$-glucose to its polyol derivative, sorbitol, and its subsequent oxidation to $\mathrm{D}$-fructose by the following reactions:

$$
\begin{aligned}
& \text { 1. } \mathrm{D}-\mathrm{Glucose}+\mathrm{NADPH}+\mathrm{H}^{+} \\
& \text {Alditol:NADP oxidoreductase } \\
& \text { sorbitol }+\mathrm{NADP}^{+} \\
& \text {(aldose reductase) }
\end{aligned}
$$

\section{Sorbitol $+\mathrm{NAD}^{+}$}

$$
\begin{aligned}
& \text { L-iditol :NAD oxidoreductase } \\
& \text { (sorbitol dehydrogenase). }
\end{aligned}
$$

The polyol pathway provides the mechanism for the synthesis of seminal fluid fructose in the accessory glands of the male genital tract (2), and of fetal plasma fructose in the placenta $(3,4)$. The physiological function of this pathway in other tissues is presently unknown. However, the presence of the polyol pathway in a tissue in which the intracellular transport of glucose is not rate limiting for its phosphorylation provides the basis of a pathological mechanism by which elevated plasma glucose concentrations result in cataract formation in experimental diabetes $(5,6)$.

In studies previously reported, we observed that insulin added in vitro does not alter the glucose space in 
aortic intima and media from normal or alloxan-diabetic rabbits, and that intracellular transport is not limiting for glucose phosphorylation in this tissue (79). Both alditol: NADP oxidoreductase and L-iditol: NAD oxidoreductase activities were demonstrated in the thoracic aortas of humans and rabbits (1). In addition, the sorbitol content of rabbit aorta was found to rise with increasing medium glucose concentrations during incubation in vitro (1). These observations suggested that the polyol pathway is operative in aortic intima and media, and that its activity is regulated, in part, by the ambient glucose concentration. The studies reported below concern the characteristics of the enzymes of the polyol pathway in rabbit aorta, and the effects of elevated medium glucose concentrations on polyol pathway activity, water content, and respiration in this tissue.

\section{METHODS}

Young, male, New Zealand rabbits $(1.5-2.0 \mathrm{~kg}$ ) were fed Wayne Rabbit Ration (Allied Mills, Inc., Chicago, Ill.) plus carrots and lettuce ad lib. They were sacrificed by decapitation. The descending thoracic aorta was rapidly removed, and dissected free of adipose tissue and adventitia by means of watchmaker's forceps while the tissue was immersed in Krebs-Ringer-bicarbonate buffer (KRB) ${ }^{\mathbf{1}}, \mathrm{pH}$ 7.4 , continuously bubbled with $5 \% \mathrm{CO}_{2}$ in air (KRB-CO $/$ air). The details of this technique have been reported previously $(7,8)$. The aorta was then cut into six equal segments, approximately $1 \mathrm{~cm}$ in length, that were designated 1 through 6 according to proximal to distal anatomical origin. The odd- and even-numbered segments were pooled. to provide two paired samples $(100-125 \mathrm{mg})$ from each aorta. Odd- and even-numbered samples were alternately assigned to each of the two test conditions examined in any series of paired experiments. The samples were blotted, quickly weighed on a torsion balance, and transferred to 25-ml Erlenmeyer flasks containing $5.0 \mathrm{ml}$ of $\mathrm{KRB}-\mathrm{CO}_{2} /$ air plus appropriate substrate. The samples were incubated at $37^{\circ} \mathrm{C}$ in a Dubnoff metabolic shaker at $88 \mathrm{cpm}$ for the times indicated in the text. The total time elapsed from decapitation to the start of the incubation did not exceed 10 min. Histological examination of the tubular segments indicates that they are comprised of intima and media only. In previous studies we have established that paired samples from a single aorta exhibit similar rates of glucose uptake, lactate production, oxygen uptake, and ${ }^{14} \mathrm{CO}_{2}$ production from glucose- $U-{ }^{14} \mathrm{C}$ when incubated for 2 or $3 \mathrm{hr}$ with $5 \mathrm{~mm}$ glucose; the oxygen uptake is linear throughout this period (7-9).

At the end of the incubation the aortic tissue was rapidly removed, placed in $1.0 \mathrm{ml}$ of cold $6 \% \mathrm{HClO}_{4}$, and homogenized by hand in an all-glass homogenizer. Control experiments demonstrated that the values for aortic sorbitol and fructose obtained from samples handled in this fashion were not significantly different from those observed in paired samples that were quickly frozen in liquid $\mathrm{N}_{2}$ before homogenization in cold $6 \% \mathrm{HClO}_{4}$. (Prior freezing markedly increases the difficulty of homogenizing this tissue.)

${ }^{1}$ Abbreviation used in this paper: KRB, Krebs-Ringerharcarbonate buffer.
The homogenate was centrifuged at $4500 \mathrm{~g}$ at $2^{\circ} \mathrm{C}$ for 15 min; portions of the resulting supernate were neutralized to pH 7.0 with $2 \times \mathrm{KOH}$ at $4^{\circ} \mathrm{C}$, and left to stand at the same temperature for $30 \mathrm{~min}$. The excess $\mathrm{KClO}_{4}$ was removed by centrifugation at $3000 \mathrm{~g}$ for $15 \mathrm{~min}$ at $2^{\circ} \mathrm{C}$. Neutralized perchloric-acid filtrates of the media were prepared in a similar fashion to that described above; in the initial step $4.0-\mathrm{ml}$ portions of the media were pipette into tubes containing $0.38 \mathrm{ml}$ of $70 \% \mathrm{HClO}_{4}$ at $4^{\circ} \mathrm{C}$; final $\mathrm{HClO}_{4}$ concentration $6 \%$. Portions of the neutralized filtrates prepared from the tissue and medium were analyzed for sorbitol and fructose by fluorometric enzymatic assays previously described (10), using an Eppendorf fluorometer modified according to the recommendations of Estabrook, Williamson, Frenkel, and Maitra (11).

Gas-liquid chromatographic identification of fructose and sorbitol (hexitol) in aortic tissue was carried out as previously described (10). Xylulose and/or xylitol were not demonstrable in the aortic filtrates by this method. Lactate was determined in the neutralized perchloric-acid filtrates by the method of Hohorst (12), and pyruvate was assayed by the method of Lowry, Passonneau, Hasselberger, and Schultz (13). In those experiments in which glucose uptake was determined, $\mathrm{Ba}(\mathrm{OH})_{2}-\mathrm{ZnSO}_{4}$ filtrates of the media were prepared and analyzed for glucose by means of glucose oxidase (Glucostat, Worthington Biochemical Corp., Freehold, N. J.) ; the reaction was permitted to continue for $45 \mathrm{~min}$ at $37^{\circ} \mathrm{C}$.

In experiments in which the water content of the tissue was determined, aortic segments from three rabbits were pooled to provide three matched samples; each sample contained all of the six anatomical segments of the thoracic aota with a third of the segments derived from each of the three rabbits. The incubation was carried out in KRB$\mathrm{CO}_{2}$ /air containing appropriate substrate for $3 \mathrm{hr}$ at $37^{\circ} \mathrm{C}$. After incubation the pooled samples were quickly blotted between pads of filter paper, and transferred to tared $5.0-\mathrm{ml}$ beakers and weighed on a Mettler model H20T analytical balance $(d=0.01 \mathrm{mg})$ (Mettler Instrument Corp., Princeton, N. J.). The vessels were then placed in a vented oven at $99^{\circ} \mathrm{C}$ and the samples dried to a constant weight; this usually required $48 \mathrm{hr}$.

The inulin space in aortic samples incubated with glucose was determined by incubating paired aortic samples in 5.0 $\mathrm{ml}$ of $\mathrm{KRB}-\mathrm{CO}_{2} /$ air containing 5 or $50 \mathrm{mM}$ glucose at $37^{\circ} \mathrm{C}$ for $2 \mathrm{hr}$. $12 \mu \mathrm{Ci}$ methoxy- $\left({ }^{3} \mathrm{H}\right)$-inulin, $\mathrm{SA} 0.178 \mathrm{mCi} / \mathrm{mg}$ (New England Nuclear, Boston, Mass.), was added to each flask at the start of the incubation in a volume of 0.01 $\mathrm{ml}$. At the end of the incubation the tissue was rapidly blotted, weighed on an analytical balance, and homogenized in $4.0 \mathrm{ml}$ of $5 \% \mathrm{ZnSO}_{4} ; 4.0 \mathrm{ml}$ of a balanced $\mathrm{Ba}(\mathrm{OH})_{2}$ solution $(0.3 \mathrm{M})$ was added and the homogenization repeated. After centrifugation, $0.1-\mathrm{ml}$ portions of the supernate were dispersed in $10 \mathrm{ml}$ of Aquasol (New England Nuclear) in a glass counting vial by means of a Vortex mixer. The samples were counted in an Intertechnique liquid scintillation spectrometer (model ABAC SL 40, Intertechnique Instruments, Inc., Dover, N. J.) with an internal standard. $\mathrm{Ba}(\mathrm{OH})_{2}-\mathrm{ZnSO}_{4}$ filtrates were prepared from incubation medium from each vessel and $0.01-\mathrm{ml}$ portions of the filtrate were prepared and counted in the same fashion. In six of the experiments listed in Table $\mathrm{V} b$ an estimate of intracellular glucose concentration was also obtained. The glucose concentration in filtrates of the tissue homogenates and media was determined by glucose oxidase. The intracellular glucose was calculated as the total tissue 
TABLE I

.Lortic Sorbitol and Fructose Concentrations and Release of Fructose into the Medium during Incubation with Glucose $(5 \mathrm{mM})$

\begin{tabular}{lrrrrrr}
\hline & \multicolumn{5}{c}{ Duration of incubation } \\
\cline { 2 - 6 } & $30 \mathrm{~min}$ & $n \ddagger$ & $1 \mathrm{hr}$ & $n$ & $2 \mathrm{hr}$ \\
\hline Aortic sorbitol, nmoles $/ \mathrm{g}$ wet weight & $11.0 \pm 0.45^{*}$ & $(14)$ & $11.4 \pm 1.05$ & $(14)$ & $12.9 \pm 0.87$ & $(15)$ \\
Aortic fructose, nmoles $/ \mathrm{g}$ wet weight & $18.2 \pm 1.47$ & $(9)$ & $31.6 \pm 2.72$ & $(9)$ & $34.3 \pm 3.74$ & $(9 ;$ \\
Fructose release, nmoles $/ g$ wet weight & $+0.9 \pm 3.35$ & $(8)$ & $82.8 \pm 10.8$ & $(8)$ & $214.0 \pm 21.1$ & $(8)$
\end{tabular}

Aortic intima and media incubated in $\mathrm{KRB}-\mathrm{CO}_{2} /$ air at $37^{\circ} \mathrm{C}$. These data were compiled from studies in which tissues from different groups of rabbits were used for each of the incubation times examined.

* Values are the mean \pm sk.

$\ddagger$ Number of animals.

glucose minus the product of the inulin space and the medium glucose concentration. The total water content of tissue was assumed to be $73.6 \%$ of the wet weight in samples incubated with $5 \mathrm{~mm}$ glucose and $75.1 \%$ of wet weight in samples incubated with $50 \mathrm{~mm}$ glucose. These average values are derived from the data in Table $\mathrm{Va}$. Intracellular fluid volume was calculated as the difference between the total water and the inulin space.

Oxygen uptake was determined by means of a model 53 biological oxygen monitor, Yellow Springs Instrument Co., Yellow Springs, Ohio.

Young (4 months) male rabbits were made diabetic by the intravenous injection of alloxan monohydrate $(75 \mathrm{mg} /$ $\mathrm{kg}$ ) after an overnight fast, and were subsequently fed ad lib. After $3 \mathrm{wk}$, animals whose random plasma glucose concentration exceeded $300 \mathrm{mg} / 100 \mathrm{ml}$ were sacrificed, and the water content of their thoracic aortas determined as described above. In additional experiments tubular segments of aortic intima and media were prepared from the thoracic aortas of alloxan-diabetic rabbits, and the oxygen uptake of the freshly prepared tissue was determined in $\mathrm{KRB}-\mathrm{CO}_{2} /$ air containing glucose in the concentration found in the animal's plasma at sacrifice. In these experiments plasma glucose was rapidly determined by means of a Beckman glucose analyzer (Beckman Instruments, Inc., Fullerton, Calif.). Aortas from normal male rabbits of the same age were studied concurrently.

To isolate rabbit aortic alditol: NADP oxidoreductase and L-iditol: NAD oxidoreductase, batches of 600 frozen young rabbit thoracic aortas (Pel-Freez Bio-Animals, Inc., Rogers, Ark.) were homogenized for $2 \mathrm{~min}$ at $4^{\circ} \mathrm{C}$ in a Waring Blendor in $6 \mathrm{vol}$ of potassium phosphate buffer (5 $\mathrm{mm}), \mathrm{pH}$ 6.8, containing 2-mercaptoethanol (1 $\mathrm{mm}$ ) (subsequently referred to as the standard buffer solution). All subsequent steps were carried out at $4^{\circ} \mathrm{C}$. After centrifugation at $20,000 \mathrm{~g}$ for $30 \mathrm{~min}$ the protein content of the supernate was determined (14) and aged calcium phosphate gel was added $(2.0 \mathrm{~g} / \mathrm{g}$ protein) and the solution stirred for $1 \mathrm{hr}$. The gel and adsorbed inactive protein were removed by centrifugation at $20,000 \mathrm{~g}$ for $30 \mathrm{~min}$. The supernatant solution was subjected to ammonium sulfate fraction by the repeated addition of solid ammonium sulfate followed by centrifugation. The fraction precipitating between 40 and $80 \%$ saturation with ammonium sulfate was dissolved in a small volume of the standard buffer solution. The protein solution was desalted by gel filtration on a 2.5 $\times 85 \mathrm{~cm}$ column of Sephadex G-50 pre-equilibrated with standard buffer solution, and applied to a $2.5 \times 25 \mathrm{~cm}$ column of DEAE-cellulose pre-equilibrated with the standard buffer solution. The column was washed with $200 \mathrm{ml}$ of the same buffer solution and developed with $700 \mathrm{ml}$ of a linear gradient of potassium phosphate buffer (5-25 $\mathrm{mm}$ ), $\mathrm{pH}$ 6.8, containing 2-mercaptoethanol (1 mM). 10-ml fractions were collected. (L-Iditol: NAD oxidoreductase does not bind to the column under these conditions and is recovered in the run-off and washings.) Two peaks of polyol: NADP oxidoreductase activity were eluted from the DEAEcellulose column. Alditol: NADP oxidoreductase eluted between 14 and $17 \mathrm{~mm}$ phosphate, and L-gulonate: NADP oxidoreductase eluted between 19 and $23 \mathrm{~mm}$ phosphate. The pooled fractions containing the peak of alditol: NADP oxidoreductase activity were brought to $80 \%$ saturation with ammonium sulfate; the resulting precipitate was dissolved in a small volume of the standard buffer solution and applied to a $2.5 \times 85 \mathrm{~cm}$ column of Sephadex G-100 preequilibrated with the standard buffer, and the column was developed with the same buffer. A single peak of alditol: NADP oxidoreductase activity was recovered. The pooled activity was precipitated by bringing the solution to $80 \%$ saturation with ammonium sulfate and stored in the cold. Before study, the precipitate was dissolved in $1.0 \mathrm{ml}$ of potassium phosphate buffer $(50 \mathrm{~mm}), \mathrm{pH} 6.8$, containing 2-mercaptoethanol ( $1 \mathrm{~mm}$ ) and desalted by gel filtration on a $1.5 \times 15 \mathrm{~cm}$ column of Sephadex G-50 pre-equilibrated with the same buffer. This isolation procedure resulted in approximately a 163-fold purification of aortic alditol: NADP oxidoreductase with a final SA of $196 \mu$ moles/min per $g$ protein. Some of the kinetic characteristics of the alditol: NADP oxidoreductase recovered from the DEAEcellulose column have previously been reported (1). The data presented in the text and Table III are derived from six preparations which were subjected to a subsequent gel filtration step with a further 2.5-fold purification. These preparations consistently exhibited lower $K_{m}$ for D-glucose and $\mathrm{D}$-xylose than those previously reported (1).

The run-off and washings from the DEAE-cellulose column which contained the aortic L-iditol: NAD oxidoreductase activity were brought to $90 \%$ saturation with solid ammonium sulfate and the protein precipitate was recovered. The precipitate was dissolved in potassium phosphate buffer ( $5 \mathrm{~mm}$ ), $\mathrm{pH} 6.2$, containing 2-mercaptoethanol $(1 \mathrm{~mm})$ and desalted by gel filtration on a column of Sephadex G-50 pre-equilibrated with the same buffer. The protein solution was applied to a $2.5 \times 15 \mathrm{~cm}$ column of carboxymethylcellulose (Whatman CM-52) pre-equilibrated with the same buffer, and developed with $500 \mathrm{ml}$ of a linear gradient of 
TABLE II

Effect of Medium Glucose Concentration on Polyol Palhway Activity in .t orla

\begin{tabular}{|c|c|c|c|c|}
\hline & $\begin{array}{c}\text { Glucose } \\
(5 \mathrm{~mm})\end{array}$ & $\begin{array}{l}\text { Glucose } \\
(20 \mathrm{~mm})\end{array}$ & Mean $\Delta \pm \mathrm{SE}$ & $P^{*}$ \\
\hline \multicolumn{5}{|l|}{ a. $\mathrm{N}=8$} \\
\hline Aortic sorbitol, nmoles/g wet weight & $11.5 \pm 0.5 \ddagger$ & $19.1 \pm 0.7$ & $+7.6 \pm 0.8$ & $<0.001$ \\
\hline Aortic fructose, nmoles $/ g$ wet weight & $35.0 \pm 2.3$ & $60.7 \pm 4.0$ & $+25.7 \pm 2.7$ & $<0.001$ \\
\hline \multirow[t]{2}{*}{ Medium fructose, nmoles $/ g$ wet weight per $2 \mathrm{hr}$} & $216 \pm 18$ & $780 \pm 81$ & $+564 \pm 69$ & $<0.001$ \\
\hline & $\begin{array}{l}\text { Glucose } \\
(5 \mathrm{~mm})\end{array}$ & $\begin{array}{l}\text { Glucose } \\
\text { (50 mM) }\end{array}$ & Mean $\Delta \pm$ SE & $P^{p *}$ \\
\hline \multicolumn{5}{|l|}{ b. $N=7$} \\
\hline Aortic sorbitol, nmoles/g wet weight & $11.7 \pm 0.9$ & $30.1 \pm 3.1$ & $+18.4 \pm 2.3$ & $<0.001$ \\
\hline Aortic fructose, $n$ moles $/ g$ wet weight & $34.7 \pm 6.5$ & $84.9 \pm 11.9$ & $+50.2 \pm 8.1$ & $<0.001$ \\
\hline Medium fructose, nmoles $/ g$ wet weight per $2 \mathrm{hr}$ & $216 \pm 24$ & $1430 \pm 54$ & $+1214 \pm 166$ & $<0.001$ \\
\hline
\end{tabular}

Paired samples incubated in $\mathrm{KRB}-\mathrm{CO}_{2} /$ air for $2 \mathrm{hr}$ at $37^{\circ} \mathrm{C}$ with glucose in the concentrations indicated.

* $P$ determined by analysis of differences between values at the higher glucose concentration and at $5 \mathrm{~mm}$ glucose in the individual paired experiments by the $t$ test for paired comparisons (15).

$\ddagger \mathrm{SE}$ of groups was computed for comparison with data in other tables.

potassium phosphate buffer ( $5-100 \mathrm{~mm}), \mathrm{pH} 6.2$, containing 2-mercaptoethanol ( $1 \mathrm{~mm})$. A single peak of $\mathrm{L}$-iditol:NAI) oxidoreductase activity eluted between 60 and $65 \mathrm{~mm}$ phosphate, and was used for subsequent studies. This preparation had a specific activity of $17 \mu$ moles/min per g protein which represented a 69 -fold purification.

Enzymatic activities were determined spectrophotometrically at $340 \mathrm{~nm}$ with a Gilford model 240 recording spectrophotometer (Gilford Instrument Laboratories, Inc., Oberlin, Ohio) at $30^{\circ} \mathrm{C}$. Alditol: NADP oxidoreductase activity was determined in $1.0 \mathrm{ml}$ of potassium phosphate buffer (60 $\mathrm{mm}), \mathrm{pH} 6.2$, containing D-xylose $(400 \mathrm{~mm})$ and NADPH $(0.1 \mathrm{~mm})$. The reaction remained linear for 5 min, and the rates were linearly related to the amount of enzyme added at all stages of the purification. L-Iditol: NAD oxidoreductase activity was assayed in $1.0 \mathrm{ml}$ glycine$\mathrm{NaOH}$ buffer $(50 \mathrm{~mm}), \mathrm{pH} 9.6$, containing L-arabitol (100 $\mathrm{mm})$ or sorbitol $(10 \mathrm{~mm})$ and NAD $(3 \mathrm{~mm})$.

As indicated in the text, most of the incubation experiments employed paired tissue samples and the differences between paired samples were analyzed for significance by the $t$ test for paired comparisons (15). However, in some cases the mean and standard error of the mean for the groups in any series of experiments were also computed to permit comparison with data obtained in other series of experiments.

\section{RESULTS}

During the preparation of aortic intima and media for incubation the tissue is exposed to large volumes of substrate-free buffer, and its sorbitol content usually decreases during this period. However, during subsequent incubation with $5 \mathrm{~mm}$ glucose, the sorbitol content reaches a level within $30 \mathrm{~min}$ that remains relatively constant throughout a $2 \mathrm{hr}$ incubation (Table I). In contrast, the aortic fructose content continues to rise over the $1 \mathrm{st} \mathrm{hr}$ and then appears to plateau (Table I). During the $2 \mathrm{hr}$ incubation with $5 \mathrm{~mm}$ glucose the quantity of free fructose released into the medium wats six times the steady-state aortic fructose content, and 17 times the molar equivalent of the steady-state aortic sorbitol content (Table I). Sorbitol could not be detected in the medium at any glucose concentration. These observations suggest that there is a significant turnover of sorbitol in the aorta at a physiological medium glucose concentration. Further, it is apparent that the quantity of glucose utilized for sorbitol synthesis cannot be accurately estimated from the aortic sorbitol content alone. However, a rough estimate may be obtained from the quantity of fructose released into the medium during the incubation. This requires the assumption that the polyol pathway operates in an essentially irreversible fashion in the aorta as it does in sheep seminal vesicles (16), and in human erythrocytes (10). This assumption appears to be justified since incubation of aortic tissue with fructose concentrations as high as $50 \mathrm{~mm}$ failed to increase the aortic sorbitol or glucose concentrations above that observed in the absence of added substrate. (As recently noted by Atkinson (17) and earlier by Klingenberg and Bücher (18), the difference in the redox states of the free $\mathrm{NADP}^{+} / \mathrm{NADPH}$ and free $\mathrm{NAD}^{+} / \mathrm{NADH}$ couples in the cytoplasm of many cells is such that under physiological conditions the free energy change for the reduction of $\mathrm{NAD}^{+}$by NADPH, such as occurs in the conversion of glucose to fructose via the polyol pathway, would be of the order of the free energy of hydrolysis of the $\gamma$-phosphate of adenosine triphosphate (ATP). As noted by Klingenberg and Bücher (18), this appears to be the basis of the apparent irreversibility of the polyol pathway.) The estimate of polyol 
TABLE III

Rabbit Aortic Alditol: NADP Oxidoreduclasc

\begin{tabular}{|c|c|c|}
\hline Substrate. & $K_{m}$ & $\begin{array}{c}V_{\max } \\
\text { (relative to } \\
\text { 1)-glyceraldehyde) }\end{array}$ \\
\hline D-Glyceraldehyde & $1.2 \times 10^{-4.11}$ & 10() \\
\hline 1)-Erythrose & $2.3 \times 10+.11$ & 54 \\
\hline 1)-Ribose & $2.0 \times 10^{2} .11$ & 29 \\
\hline D-Xylose & $1.5 \times 10^{-2} \mathrm{n}$ & 2.3 \\
\hline D-Arabinose & $1.1 \times 10^{-1} \mathrm{M}$ & 8 \\
\hline 1,-Arabinose & $4.2 \times 10^{-2} \mathrm{M}$ & $4+$ \\
\hline I)-Lyxose & $7.0 \times 10^{-2} \mathrm{M}$ & 87 \\
\hline 1)-Galactose & $2.9 \times 10^{-1} \mathrm{n}$ & 22 \\
\hline D)-Glucose & $5.6 \times 10^{-2} .11$ & 23 \\
\hline D-Mannose & $3.5 \times 10^{-1} \mathrm{M}$ & 8 \\
\hline I)-Glucuronic acid & $3.7 \times 10^{-2} \mathrm{M}$ & 77 \\
\hline D-Glucuronolactone & $6.0 \times 10^{-3} \mathrm{M}$ & 44 \\
\hline D)-Galacturonic acid & $5.6 \times 10^{-2} \mathrm{M}$ & 47 \\
\hline NADPH & $6.0 \times 10^{-6} . .1$ & \\
\hline
\end{tabular}

The $K_{m}$ for aldoses and uronic acids were determined at $30^{\circ} \mathrm{C}$ in $1.0 \mathrm{ml}$ of potassium phosphate buffer, pH $6.2(0.06 \mathrm{M})$, containing $\mathrm{NADPH}\left(1 \times 10^{-4} \mathrm{M}\right)$. The $K_{m}$ for NADPH was determined under the same conditions with D-xylose $\left(1.5 \times 10^{-1} \mathrm{M}\right)$ as substrate.

pathway activity derived from fructose recovered in the medium would be a minimal estimate, since it would not assess any sorbitol or fructose metabolized by other pathways.

Paired aortic samples were incubated with either 5 and $20 \mathrm{~mm}$ or with 5 and $50 \mathrm{~mm}$ glucose for $2 \mathrm{hr}$ to

TABLE IV

L-Iditol:NAD Oxidoreductase from Rabbit Thoracic A erta

\begin{tabular}{lcc}
\hline \multicolumn{1}{c}{ Substrate } & $K_{m}$ & $\begin{array}{c}\mathrm{V}_{\max } \\
\text { (relative to sorbitol) }\end{array}$ \\
Sorbitol & $m \mathrm{M}$ & \\
Dulcitol & 0.7 & 100 \\
Xylitol & 98.0 & 43 \\
Ribitol & 0.2 & 110 \\
L-Arabitol & 10.0 & 81 \\
NAD & 8.7 & +6 \\
Fructose & 0.0 .4 & \\
NADH & 83.0 & \\
\hline
\end{tabular}

The $K_{m}$ for hexitols and pentitols were determined at $30^{\circ} \mathrm{C}$ in $1.0 \mathrm{ml}$ of glycine- $\mathrm{NaOH}$ buffer $\left(5 \times 10^{-2} \mathrm{M}\right)$, $\mathrm{pH} 9.6$, containing NAD $\left(3 \times 10^{-3} \mathrm{M}\right)$. The $K_{m}$ for NAD was determined under the same conditions with sorbitol $\left(1.0 \times 10^{-2} \mathrm{M}\right)$ as substrate. The $K_{m}$ for fructose was determined at the same temperature in $1.0 \mathrm{ml}$ of potassium phosphate buffer, $\mathrm{pH}$ $6.2\left(6.0 \times 10^{-2} \mathrm{M}\right)$, containing $\mathrm{NADH}\left(4.0 \times 10^{-4} \mathrm{M}\right)$; the $K_{m}$ for NADH was determined in the same system with fructose $\left(5 \times 10^{-1} \mathrm{M}\right)$ as substrate. examine the effects of medium glucose concentration on polyol pathway activity (Table II). The samples incubated with $5 \mathrm{~mm}$ glucose released 216 nmoles of free fructose/g wet weight per $2 \mathrm{hr}$ which accounted for approximately $1.8 \%$ of the glucose uptake. (Average glucose uptake $=11.6 \pm 0.7 \mu$ moles $/ g$ wet weight per $2 \mathrm{hr} ; \mathrm{N}=15$.) Increasing the medium glucose concen tration to 20 or $50 \mathrm{~mm}$ resulted in the expected increases in aortic sorbitol content and in significant increases in aortic fructose content (Table II). The fructose recovered in the medium increased 3.5-fold when the medium glucose was increased from 5 to 20 $\mathrm{mm}$, and more than 6-fold when the medium glucose was increased from 5 to $50 \mathrm{~mm}$ (Table II). Thus an elevated medium glucose concentration appears to produce an increase in both sorbitol synthesis and sorbitol oxidation to fructose. (The per cent of the glucose uptake utilized via the polyol pathway at 20 or $50 \mathrm{~mm}$ glucose cannot be accurately estimated because of the difficulty in accurately deternining glucose uptake at these medium glucose concentrations.)

The increased polyol pathway activity observed at elevated medium glucose concentrations can be explained in terms of the kinetic characteristics of the enzymes concerned with sorbitol synthesis and oxidation in rabbit aorta. Aortic alditol: NADP oxidoreductase resembles the enzyme originally described in sheep seminal vesicles (2) in its capacity to catalyze the NADPH-dependent reduction of a wide range of aldoses, as well as uronic acids (Table III). It also exhibits the high $K_{m}$ for aldohexoses which have been characteristic of the alditol: NADP oxidoreductases isolated from a number of mammalian tissues $(2,19,20)$ and from human placenta (4) (Table III). Aortic alditol: NADP oxidoreductase has an apparent $K_{m}$ for glucose of $5.6 \times 10^{-2} \mathrm{M}$. Thus an increase in intracellular glucose concentration would be expected to result in increased sorbitol synthesis over a wide range. This appears to be a reasonable explanation for the effect of an increased medium glucose concentration on the rate of sorbitol synthesis, since the intracellular glucose concentration averaged $3.64 \pm 0.28 \mathrm{~mm}$ in tissue incubated with $5 \mathrm{~mm}$ glucose for $2 \mathrm{hr}$, and $26.48 \pm 4.78 \mathrm{~mm}$ in paired samples incubated with $50 \mathrm{~mm}$ glucose, $n=6$ (see Methods).

Rabbit aortic L-iditol: NAD oxidoreductase catalyzes the NAD-dependent oxidation of sorbitol to fructose, and resembles hepatic sorbitol dehydrogenase in that L-arabitol is oxidized as well as polyols having a cis2,4-dihydroxy configuration (21) (Table IV). The apparent $K_{m}$ for sorbitol of the aortic enzyme is $0.7 \mathrm{~mm}$. If one assumes that the sorbitol present in rabbit aortic intima and media is uniformly distributed in intracellular water, the intracellular sorbitol concentration in tissue incubated with $5 \mathrm{~mm}$ glucose for $\frac{1}{2}-2 \mathrm{hr}$ would be of 
the order of $0.04 \mathrm{~mm}$. This estimate is derived from the aortic sorbitol levels in Tables I and II, and from data which indicate that under these conditions the average water content of aortic tissue is $73.6 \pm 0.3 \%$ of the wet weight (Table $\mathrm{Va}$ ), and the average inulin space is $56.7 \pm 1.5 \%$ of the tissue water (9). Since the steadystate intracellular sorbitol concentration in aortic tissue incubated with $5 \mathrm{~mm}$ glucose appears to be less than $\frac{1}{10}$ the $K_{m}$ for sorbitol of L-iditol: NAD oxidoreductase, the rise in aortic sorbitol that results from an increase in nedium glucose concentration (Table II) would explain the increased rate of sorbitol oxidation to fructose.

The possibility that incubation with elevated glucose concentrations results in an increase in the water content of aortic intima and media was examined. In control experiments the water content of paired aortic samples was determined immediately after preparation and after a $3 \mathrm{hr}$ incubation with $5 \mathrm{~mm}$ glucose and no significant difference was observed. Subsequently, matched pooled samples of aortic tissue (see Methods) were incubated withr 5, 20, and $40 \mathrm{~mm}$ glucose for $3 \mathrm{hr}$. As shown in Fig. 1, the water content of the samples incubated with 20 or $40 \mathrm{~mm}$ glucose was significantly greater than that of the matched samples incubated with $5 \mathrm{~mm}$ glucose. The most striking increase in water content, averaging $+5 \%$, was observed when medium glucose was increased from 5 to $20 \mathrm{~mm}$ (Fig. 1). With a single exception, a further, but smaller, increase was observed when the medium glucose was increased from 20 to $40 \mathrm{~mm}$ (Fig. 1). The notation used to express the water content of the tissue, i.e., $\mathrm{g} / 100 \mathrm{~g}$ dry weight, was chosen to conform with that employed by Tobian and his associates in their studies of the water content of the arterial and arteriolar walls in experimental hypertension $(22,23)$.

A significant increase in water content could also be demonstrated in aortic tissue that had been incubated with $50 \mathrm{~mm}$ glucose for $2 \mathrm{hr}$ (Table $\mathrm{Va}$ ). Under these conditions the inulin space in tissue incubated with 50

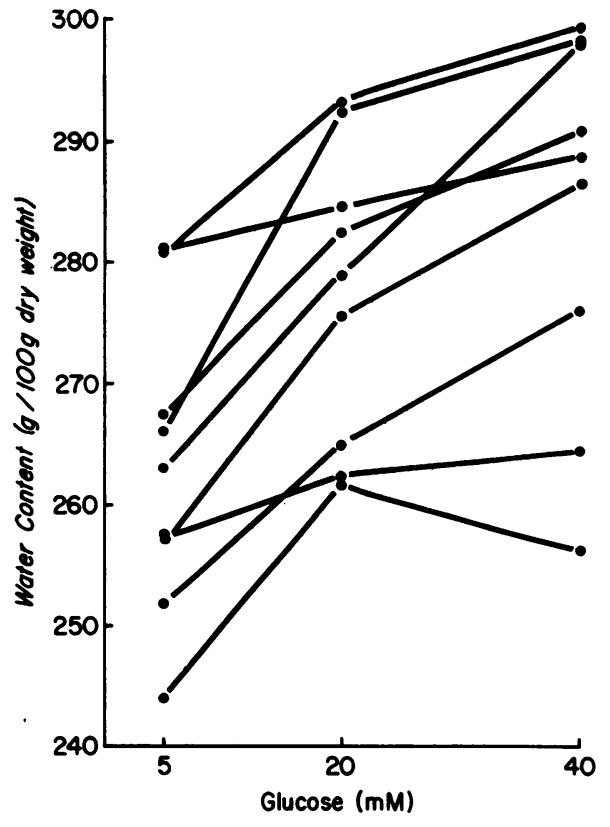

FIGURE 1 Effect of medium glucose concentration on the water content of aortic intima and media. In each experiment matched samples from three rabbits (see Methods) were incubated for $3 \mathrm{hr}$ in $\mathrm{KRB}-\mathrm{CO}_{2} /$ air with glucose in the concentrations indicated at $37^{\circ} \mathrm{C}$. The mean $\Delta$ in water content between matched samples incubated with 5 and 20 mM glucose was $+14.2 \pm 2.3 \mathrm{~g} / 100 \mathrm{~g}$ dry weight, $P<0.001$. The mean $\Delta$ in water content between matched samples incubated with 5 and $40 \mathrm{~mm}$ glucose was $+21.0 \pm 3.5 \mathrm{~g} /$ 100 . g dry weight, $P<0.001$.

mM glucose was consistently less than that of paired samples incubated with $5 \mathrm{~mm}$ glucose (Table $\mathrm{V} b$ ). Thus the increased water content does not appear to result from an increase in the inulin space.

The water content of aortic tissue incubated with 40 $\mathrm{mm}$ fructose was not significantly different from that of paired controls incubated with $5 \mathrm{~mm}$ fructose; mean $\Delta$ of

TABLE V

Effect of Medium Glucose Concentration on Water Content and Inulin Space of Aortic Tissue Incubated for $2 \mathrm{hr}$

\begin{tabular}{|c|c|c|c|c|}
\hline & $\begin{array}{c}\text { Glucose } \\
(5 \mathrm{~mm})\end{array}$ & $\begin{array}{l}\text { Glucose } \\
(50 \mathrm{~mm})\end{array}$ & $\begin{array}{c}\text { Mean } \Delta \text { of paired } \\
\quad \text { exp. } \pm \mathrm{SE}\end{array}$ & $P$ \\
\hline \multicolumn{5}{|c|}{ a. Water content, $g \mathrm{H}_{2} \mathrm{O} / 100 \mathrm{~g}$ dry weight } \\
\hline $\mathrm{N}=10$ & $280.8 \pm 3.5$ & $300.7 \pm 3.9$ & $+19.8 \pm 3.0$ & $<0.001$ \\
\hline \multicolumn{5}{|c|}{ b. Inulin space, $m l \mathrm{H}_{2} \mathrm{O} / g$ wet weight } \\
\hline $\mathrm{N}=9$ & $0.501 \pm 0.024$ & $0.484 \pm 0.025$ & $-0.017 \pm 0.004$ & $<0.01$ \\
\hline
\end{tabular}

Paired aortic samples were incubated in $\mathrm{KRB}-\mathrm{CO}_{2} /$ air at $37^{\circ} \mathrm{C}$ for $2 \mathrm{hr}$. In $a$, at the end of the incubation the water content of the tissue was determined. In $b$, methoxy$\left({ }^{3} \mathrm{H}\right)$-inulin was added to the medium at the start of the incubation, and the inulin space determined as described in Methods. 


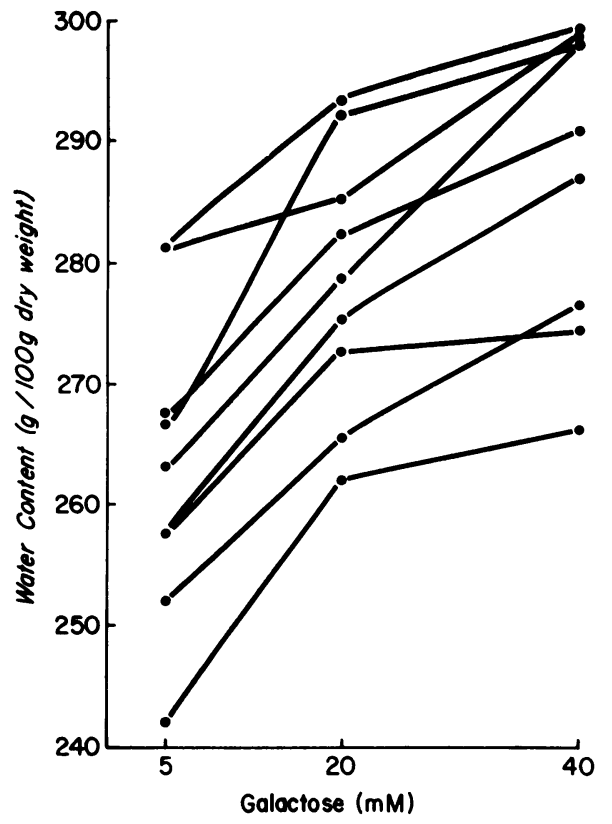

Figure 2 Effect of increasing medium galactose concentration on the water content of aortic intima and media. In each experiment, matched samples from three rabbits were incubated for $3 \mathrm{hr}$ in $\mathrm{KRB}-\mathrm{CO} /$ air containing $2 \mathrm{~ms}$ glucose and galactose in the concentrations indicated at $37^{\circ} \mathrm{C}$. The mean $\Delta$ in water content between matched samples incubated with 5 and $20 \mathrm{~mm}$ galactose was +15.4 $\pm 2.0 \mathrm{~g} / 100 \mathrm{~g}$ dry weight, $P<0.001$. The mean $\Delta$ in water content between matched samples incubated with 5 and 40 mm galactose was $+2.3 .2 \pm 2.8 \mathrm{~g} / 100 \mathrm{~g}$ dry weight. $P<0.001$.

six paired experiments $=-8.9 \pm 4.1 \quad$ g $H_{0}() 100 \mathrm{~g}$ dry weight. In these experiments 2 m.M glucose was also present as substrate. When mannitol was substituted for fructose in similar experiments the expected decreases in water content were observeil.

D-Galactose is also a substrate for aortic alditol: NADP oxidoreductase (Table III). As shown in Fig. 2, when matched samples of aortic tissue were incubated for 3 hr with 5,20 , or $40 \mathrm{~mm}$ galactose. the water content of the samples incubated with 20 or $40 \mathrm{~mm}$ galactose was

TABLE VI

Effect of Medium Glucose Concentration on Lactate Production

\begin{tabular}{|c|c|c|c|c|}
\hline \multirow[b]{2}{*}{ a. } & \multicolumn{3}{|c|}{ Lactate production, $\mu$ moles, $g$ wet ueight per $2 \mathrm{hr}$} & \multirow[b]{2}{*}{$P$} \\
\hline & $\begin{array}{l}\text { Glucose } \\
(5 \mathrm{mM})\end{array}$ & $\begin{array}{l}\text { Glucose } \\
\text { (20 mM) }\end{array}$ & $\begin{array}{l}\text { Mean } \Delta \text { of paired } \\
\text { exp. } \pm \mathrm{SE}\end{array}$ & \\
\hline$N=6$ & $10.27 \pm 0.66$ & $12.44 \pm 0.67$ & $+2.18 \pm 0.3 .3$ & $<0.01$ \\
\hline$b$. & $\begin{array}{l}\text { Glucose } \\
\text { (5 mM) }\end{array}$ & $\begin{array}{l}\text { Glucose } \\
\text { (50 mM) }\end{array}$ & $\begin{array}{c}\text { Mean } \Delta \text { of paired } \\
\text { exp. } \pm \mathrm{SE}\end{array}$ & \\
\hline$N=7$ & $10.64 \pm 1.85$ & $15.87 \pm 2.22$ & $+5.23 \pm 1.26$ & $<0.01$ \\
\hline
\end{tabular}

Paired aortic samples incubated in $\mathrm{KRB}-\mathrm{CO}_{2} /$ air at $37^{\circ} \mathrm{C}$ for $2 \mathrm{hr}$
TABLE VII

Effect of Medium Glucose Concentration on Oxyge $n$ L ptake of Aortic Tissue Preincubated for $2 \mathrm{hr}$

\begin{tabular}{|c|c|c|c|c|}
\hline & $\begin{array}{c}\text { Glucose } \\
(5 \mathrm{~mm})\end{array}$ & $\begin{array}{l}\text { Glucose } \\
(50 \mathrm{~mm})\end{array}$ & $\begin{array}{c}\text { Mean } \Delta \text { of paired } \\
\text { exp. } \pm \mathrm{SE}\end{array}$ & $P$ \\
\hline \multicolumn{5}{|c|}{ a. Oxygen uptake, $\mu l O_{2} g$ wet weight per $h r$} \\
\hline \multirow[t]{2}{*}{$x=12$} & $129 \pm i$ & $104 \pm 4$ & $-2.5 \pm .5$ & $<0.001$ \\
\hline & $\begin{array}{l}\text { Glucose } \\
(5 \mathrm{~mm})\end{array}$ & $\begin{array}{l}\text { Glucose } \\
(20 \mathrm{~mm})\end{array}$ & $\begin{array}{c}\text { Mean } \triangle \text { of paired } \\
\text { expl } \pm \text { st: }\end{array}$ & $P$ \\
\hline \multicolumn{5}{|c|}{ b. Oxygen ultake, pl O. g wert weight por hr } \\
\hline \multirow[t]{2}{*}{$x=10$} & $1.28 \pm 4$ & $115 \pm 5$ & $-1.3 \pm 2$ & $<0.001$ \\
\hline & $\begin{array}{l}\text { Glucose } \\
(5 \mathrm{mis})\end{array}$ & $\begin{array}{l}\text { (ilucose } \\
\text { (50 } \mathrm{ms})\end{array}$ & $\begin{array}{c}\text { Mean } \triangle \text { of paired } \\
(\times \mathrm{x}) . \pm \mathrm{SF}\end{array}$ & $P$ \\
\hline \multicolumn{5}{|c|}{ c. Oxygen uptake, $\mu l O_{2} g$ dry weight per hr } \\
\hline$x=10$ & $394 \pm 7$ & $3.32 \pm 7$ & $-62 \pm 5$ & $<0.001$ \\
\hline
\end{tabular}

Paired aortic samples were incubated at $37^{\circ} \mathrm{C}$ for $2 \mathrm{hr}$ in $\mathrm{KRB}-\mathrm{CO}_{2}$ air containing glucose in the stated concentrations: the oxygen uptake was then determined in medium of the same composition. The oxygen uptake did not detectably deviate from linearity during the $1.5 \mathrm{~min}$ determination.

significantly greater than that of the samples incubated with $5 \mathrm{~mm}$ galactose. (In these experiments $2 \mathrm{~mm}$ glucose was also present as substrate in all flasks.) This suggests that the effects of elevated glucose concentrations on aortic water content may be reproduced by other aldose substrataes for alditol: NADP oxidoreductase.

Lactate production accounts for approximately $80 \%$ of the glucose uptake in aortic intima and media when the medium glucose is $5 \mathrm{~mm}(7,8)$, and is thus a useful index of glucose utilization in this tissue. Aortic samples incubated with 20 or $50 \mathrm{~mm}$ glucose for $2 \mathrm{hr}$ were found to have significantly greater rates of lactate production than paired samples incubated with $5 \mathrm{~mm}$ glucose (Table VI). This observation was unexpected since the hexokinase activities in the soluble fraction of homogenates of this aortic preparation have an apparent $K_{m}$ for glucose of the order of 2.5 to $5.0 \times 10^{-4} \mathrm{M}(8)$, and there is no evidence of a glucokinase with a high $K_{m}$ for glucose such as that present in liver $(8,9)$. The intracellular glucose concentration in aortic tissue incubated with $5 \mathrm{~mm}$ glucose is of the order of $3.6 \times 10^{-3} \mathrm{M}$, and we had anticipated that the low $K_{m}$ hexokinases would be saturated under these conditions. The aortic lactate concentration was significantly higher in samples incubated with $50 \mathrm{~mm}$ glucose $(2.39 \pm 0.39 \mu$ moles $/ \mathrm{g}$ wet weight $)$ than in paired samples incubated with $5 \mathrm{~mm}$ glucose for $2 \mathrm{hr}(1.43 \pm 0.21:$ Mean $\Delta$ of seven experiments $=+0.96 \pm$ $0.29, P<0.05)$. The aortic pyruvate concentration was not significantly different in the paired samples incubated with $5 \mathrm{~mm}$ glucose $(24.5 \pm 2.2 \mathrm{nmoles} / \mathrm{g}$ wet weight $)$ and with $50 \mathrm{~mm}$ glucose $(21.6 \pm 2.2)$. Thus the aortic lactate/ pyruvate concentration ratio was significantly greater in the samples incubated with $50 \mathrm{~mm}$ glucose. Although 
TABLE VIII

Effect of $40 \mathrm{mM}$ Mannitol on Oxygen Uptake and Lactate Production of Aortic Tissue Preincubated with $50 \mathrm{mM}$ Glucose for $2 \mathrm{hr}$

\begin{tabular}{|c|c|c|c|c|}
\hline & $\begin{array}{l}\text { Glucose } \\
\text { (50 mM) }\end{array}$ & $\begin{array}{c}\text { Glucose (50 mM) } \\
+ \text { mannitol (40 mM) }\end{array}$ & $\begin{array}{l}\text { Mean } \Delta \text { of paired } \\
\quad \text { exp. } \pm \text { SE }\end{array}$ & $P$ \\
\hline \multicolumn{5}{|c|}{ a. Oxygen uptake, $\mu l \mathrm{O}_{2} / g$ wet weight per $h r$} \\
\hline $\mathrm{N}=6$ & $106 \pm 9$ & $124 \pm 11$ & $+18 \pm 2$ & $<0.001$ \\
\hline \multicolumn{5}{|c|}{ b. Oxygen uptake, $\mu l O_{2} / g d r y$ weight per $h r$} \\
\hline $\mathrm{N}=14$ & $329 \pm 8$ & $377 \pm 7$ & $+48 \pm 5$ & $<0.001$ \\
\hline \multicolumn{5}{|c|}{ c. Lactate production, $\mu$ moles $/ \mathrm{g}$ wet weight per $2 \mathrm{hr}$} \\
\hline$N=6$ & $13.86 \pm 0.98$ & $9.82 \pm 0.88$ & $-4.04 \pm 0.71$ & $<0.01$ \\
\hline
\end{tabular}

Paired aortic samples were incubated in $\mathrm{KRB}-\mathrm{CO}_{2} /$ air at $37^{\circ} \mathrm{C}$ for $2 \mathrm{hr}$, and their $\mathrm{O}_{2}$ uptake then determined in fresh medium of the same composition. The osmolality of the KRB containing $50 \mathrm{mM}$ glucose was $328 \mathrm{mOsm} / \mathrm{kg}$, and that of the KRB containing $50 \mathrm{~mm}$ glucose plus $40 \mathrm{~mm}$ mannitol was $368 \mathrm{mOsm} / \mathrm{kg}$.

the aortic wall characteristically exhibits a high rate of aerobic glycolysis, the tissue has a significant oxygen uptake and a modest Pasteur effect can be demonstrated (24). The increased aortic lactate/pyruvate ratio suggested that the increased lactate production observed in tissues incubated with elevated glucose concentrations might result from impaired respiration and de-repression of glycolysis.

The oxygen uptake of freshly prepared aortic tissue was essentially the same when the medium glucose concentration was 5 or $50 \mathrm{~mm}$ when determined in KRB$\mathrm{CO}_{2} /$ air. The oxygen uptake of the samples incubated with $5 \mathrm{~mm}$ glucose was $129 \pm 3 \mu \mathrm{l} \mathrm{O} / \mathrm{g}$ wet weight per $\mathrm{hr}$ and that of the paired samples incubated with $50 \mathrm{~mm}$ glucose was $127 \pm 3$; mean $\Delta$ of six paired experiments $=-2 \pm 1$. The oxygen uptake of aortic tissue incubated with $5 \mathrm{~mm}$ glucose remained linear for at least $3 \mathrm{hr}$ and was not acutely altered by increasing the medium glucose concentration to $50 \mathrm{~mm}$; thus a Crabtree effect could not be demonstrated. However, the oxygen uptake of aortic tissue incubated with $50 \mathrm{mlm}$ glucose tended to fall at a very slow rate after approximately $\frac{1}{2} \mathrm{hr}$. Paired aortic samples were therefore preincubated for $2 \mathrm{hr}$ with 5 or $20 \mathrm{~mm}$ and with 5 or $50 \mathrm{~mm}$ glucose and their oxygen uptakes determined in fresh media of the same composition. As shown in Table VII $a, b$, the oxygen uptakes of the samples preincubated with 20 or $50 \mathrm{~mm}$ glucose were significantly less than that of the samples preincubated with $5 \mathrm{~mm}$ glucose when compared on the basis of wet weight. The oxygen uptake of aortic tissue preincubated with $50 \mathrm{~mm}$ glucose was also significantly less than that of tissue preincubated with $5 \mathrm{~mm}$ glucose in experiments in which oxygen uptakes were compared on the basis of dry weight (Table VII $c$ ).

Paired aortic samples were preincubated for $2 \mathrm{hr}$ with $50 \mathrm{~mm}$ glucose or with $50 \mathrm{~mm}$ glucose plus $40 \mathrm{~mm}$ man- nitol, and their oxygen uptakes then determined in fresh media of the same composition. As shown in Table VIII $a$, the oxygen uptakes of the tissues preincubated with added mannitol were significantly greater than that of the samples preincubated with $50 \mathrm{~mm}$ glucose alone. This was true whether the oxygen uptake was expressed on a wet weight basis as in Table VIII $a$, or in experiments in which the dry weight was determined (Table VIII $b$ ). It should also be noted that the addition of mannitol reduced the level of lactate production during a $2 \mathrm{hr}$ incubation with $50 \mathrm{~mm}$ glucose to that observed in tissue incubated with $5 \mathrm{~mm}$ glucose (compare Table VIII $c$ with Table VI).

The oxygen uptake of aortic tissue preincubated with 5 mm glucose for $2 \mathrm{hr}$ in medium saturated with the standard gas phase $\left(5 \% \mathrm{CO}_{2}\right.$ in $95 \%$ air $)$ was the same whether the subsequent determination of oxygen uptake

TABLE IX

Effect of Oxygen Tension on Oxygen Uptake of A ortic Tissue Preincubated with Glucose for $2 \mathrm{hr}$

\begin{tabular}{|c|c|c|c|c|}
\hline & \multicolumn{3}{|c|}{ Oxygen uptake, $\mu l \mathrm{O}_{2} / g$ wet weight per $h r$} & \multirow[b]{2}{*}{$P$} \\
\hline & $\begin{array}{c}5 \% \mathrm{CO}_{2} \\
\text { in } 95 \% \text { air }\end{array}$ & $\begin{array}{c}5 \% \mathrm{CO}_{2} \\
\text { in } 95 \% \mathrm{O}_{2}\end{array}$ & $\begin{array}{c}\text { Mean } \Delta \text { of paired } \\
\text { exp. } \pm \mathrm{SE}\end{array}$ & \\
\hline \multicolumn{5}{|c|}{ a. Glucose $(5 \mathrm{~mm})$} \\
\hline$N=7$ & $1.32 \pm 6$ & $133 \pm 7$ & $0 \pm 2$ & NS \\
\hline \multicolumn{5}{|c|}{ b. Glucose (20 mM) } \\
\hline$N=7$ & $109 \pm 3$ & $12 \pi \pm 5$ & $+18 \pm 3$ & $<0.01$ \\
\hline \multicolumn{5}{|c|}{ c. Glucose $(50 \mathrm{~mm})$} \\
\hline$N=6$ & $104 \pm 6$ & $128 \pm 5$ & $+25 \pm 3$ & $<0.001$ \\
\hline
\end{tabular}

Paired aortic samples were incubated in $\mathrm{KRB}-\mathrm{CO}_{2} /$ air at $37^{\circ} \mathrm{C}$ for $2 \mathrm{hr}$ containing the same glucose concentration. The samples were then transferred to fresh media of the same composition saturated with either $5 \%$ $\mathrm{CO}_{2}$ in $95 \%$ air or $5 \% \mathrm{CO}_{2}$ in $95 \% \mathrm{O}_{2}$, and the oxygen uptake determined at $37^{\circ} \mathrm{C}$. 
TABLE X

Effect of Alloxan Diabetes on Water Content and Oxygen Uptake of Rabbit Thoracic Aorta

\begin{tabular}{|c|c|c|c|c|}
\hline Normals & $n \ddagger$ & $\begin{array}{l}\text { Alloxan } \\
\text { diabetic }\end{array}$ & $n$ & $P$ \\
\hline \multicolumn{5}{|c|}{ a. Water content, $g \mathrm{H}_{2} \mathrm{O} / 100 \mathrm{~g}$ dry weight } \\
\hline $281.4 \pm 3.1^{*}$ & 9 & $312.2 \pm 6.2$ & 9 & $<0.001 \S$ \\
\hline \multicolumn{5}{|c|}{ b. Oxygen uptake, $\mu l \mathrm{O}_{2} / g$ wet weight per $h r$} \\
\hline $131 \pm 5$ & 12 & $89 \pm 9$ & 12 & $<0.05$ \\
\hline
\end{tabular}

In $a$, the water content of freshly prepared aortic segments was determined. In $b$, oxygen uptake was determined in $\mathrm{KRB}-\mathrm{CO}_{2} /$ air at $37^{\circ} \mathrm{C}$ containing glucose in the concentration present in the animal's plasma at sacrifice; average plasma glucose in diabetics $=391 \mathrm{mg} / 100 \mathrm{ml}$, and in normals $131 \mathrm{mg} / 100 \mathrm{ml}$.

* Values are the mean \pm SF.

$\ddagger$ Number of animals.

$\S P$ determined by $t$ test of the differences between two means (15).

was carried out in medium saturated with the standard gas phase or with $5 \% \mathrm{CO}_{2}$ in $95 \%$ oxygen (Table IX). In contrast, the oxygen uptakes of aortic tissue preincubated with 20 or $50 \mathrm{~mm}$ glucose were significantly greater when determined in media saturated with $5 \%$ $\mathrm{CO}_{2}$ in $95 \%$ oxygen than in media saturated with $5 \%$ $\mathrm{CO}_{2}$ in $95 \%$ air (Table IX). The tissues preincubated with 20 or $50 \mathrm{~mm}$ glucose had rates of respiration in media saturated with $5 \% \mathrm{CO}_{2}$ in $95 \%$ oxygen that approximated that of tissue preincubated with $5 \mathrm{~mm}$ glucose (Table IX). These observations support the conclusion that oxygen diffusion becomes limiting for respiration in aortic tissue incubated with elevated glucose concentrations.

As shown in Table $\mathrm{X}$, freshly prepared aortic intima and media from alloxan-diabetic rabbits has a significantly greater water content than that from normal animals of the same age and sex. In addition, freshly prepared tissue from alloxan-diabetic rabbits exhibits a significantly reduced rate of respiration in medium saturated with the standard gas phase and containing glucose in the concentration present in the plasma at sacrifice, when compared with tissue from normal controls incubated under the same conditions (Table $\mathrm{X}$ ).

\section{DISCUSSION}

Under the in vitro conditions employed in these studies, increasing the ambient glucose concentration to levels that may be observed in the plasma of human diabetics results in significant alterations in the metabolism of the aortic wall. These alterations include an increase in glucose utilization via the polyol pathway, an increase in tissue water that lies outside the inulin space, a de- crease in respiration that results from a limitation imposed by oxygen diffusion, a compensatory increase in glycolysis, and an increase in the aortic lactate/pyruvate concentration ratio which probably reflects a change in the redox state of the free $\mathrm{NAD}^{+} / \mathrm{NADH}$ couple in the cytoplasm of component cells.

In considering the mechanism(s) responsible for the metabolic changes that result from incubating aortic tissue with elevated glucose concentrations, it would appear that after the initial half hour of incubation with high glucose concentrations, oxygen diffusion becomes limiting for respiration at medium oxygen tensions approximating that normally present in arterial blood, and there is a decrease in the respiratory rate. This appears to be responsible for the increase in glycolysis and the increase in the aortic lactate/pyruvate ratio. A relationship between the increased water content of the tissue and impaired respiration is suggested by the observations summarized in Table VIII. Thus, increasing the osmolality of the incubation medium by the addition of $40 \mathrm{~mm}$ mannitol preserves a nearly normal rate of oxygen uptake and lactate production (i.e., similar to that observed in tissue incubated with $5 \mathrm{~mm}$ glucose) in tissue incubated with $50 \mathrm{~mm}$ glucose for $2 \mathrm{hr}$. The increased water content of the tissue does not appear to result from an increase in the inulin space; however, this does not preclude the possibility that the increased water content is, in part, extracellular.

There appears to be a relationship between incubation with elevated concentrations of substrate (glucose or galactose) for aortic alditol: NADP oxidoreductase and the development of a significant increase in the water content of aortic intima and media. However, the magnitude of the increases in water content could not be explained as a consequence of the osmotic activity of the increased aortic sorbitol content observed in tissue incubated with 20 or $50 \mathrm{~mm}$ glucose. Meaningful speculation concerning the factors responsible for the increased water content must await studies of the effects of incubation with elevated glucose concentrations on the fine structure of aortic intima and media, and a better understanding of the function and the intracellular localization of the polyol pathway. Irrespective of the mechanism(s) involved, the studies reported in this communication suggest that exposure to elevated glucose concentrations results in significant alterations in the metabolism of aortic intima and media under in vitro conditions.

The observations reported herein will require confirmation in other types of aortic preparations, preferably one which permits pulsatile perfusion. The phenomena observed in these in vitro studies may not have in vivo counterparts; however, it is of interest that freshly prepared aortic intima and media from alloxan-diabetic rabbits exhibits a significantly increased water content, and 
a decreased respiratory rate when determined in medium with a physiological oxygen tension and glucose in the same concentration as that present in plasma at sacrifice. This suggests that there may be in vivo counterparts to the changes that result from incubating aortic tissue from normal rabbits with elevated glucose concentrations. However, further study is necessary to clarify the genesis of the changes observed in aortic tissue from alloxan-diabetic rabbits, since a number of factors other than hyperglycemia may be involved. Thus we have previously demonstrated that alloxan diabetes results in impaired glucose phosphorylation in rabbit thoracic aorta which is reflected in a decreased glucose uptake, a decreased rate of lactate production, and a decreased incorporation of glucose- ${ }^{14} \mathrm{C}$ into ${ }^{14} \mathrm{CO}_{2}$, glycogen, and total lipid (7-9).

The nature of the alterations produced by incubating normal aortic intima and media with elevated glucose concentrations is of interest; an increase in water content and impaired respiration have figured prominently in recent speculations concerning alterations in the metabolism of the arterial wall which might potentiate the effects of external factors that are operative in the production of arterial lesions (24-26).

\section{ACKNOWLEDGMENTS}

The authors thank Mrs. Susan Mooers, Mrs. Joan Feuer, and Miss Joanne Lubas for their expert assistance.

These studies were supported by the J. Solis-Cohen, Jr. Fund, and by National Institutes of Health Grants AM04722 and AM05556.

\section{REFERENCES}

1. Clements, R. S., Jr., A. D. Morrison, and A. I. Winegrad. 1969. Polyol pathway in aorta: regulation by hormones. Science (Wash. D. C.). 166: 1007.

2. Hers, H. G. 1957. Le mécanisme de la transformation du glucose en fructose. In Le Métabolisme du Fructose. Editions Arscia, Bruxelles. 119.

3. Britton, H. G., A. St. G. Huggett, and D. A. Nixon. 1967. Carbohydrate metabolism in the sheep placenta. Biochim. Biophys. Acta. 136: 426.

4. Clements, R. S., Jr., and A. I. Winegrad. 1972. Purification of alditol: NADP oxidoreductase from human placenta. Biochem. Biophys. Res. Commun. 47: 1473.

5. van Heyningen, R. 1962. The sorbitol pathway in the lens. Exp. Eye Res. 1: 396.

6. Chylack, L. T., Jr., and J. H. Kinoshita. 1969. A biochemical evaluation of a cataract induced in a highglucose medium. Invest. Ophthalmol. 8: 401.

7. Mulcahy, P. D., and A. I. Winegrad. 1962. Effects of insulin and alloxan diabetes on glucose metabolism in rabbit aortic tissue. Am. J. Physiol. 203: 1038.

8. Yalcin, S., and A. I. Winegrad. 1963. Defect in glucose metabolism in aortic tissue from alloxan diabetic rabbits. Am. J. Physiol. 205 : 1253.
9. Winegrad, A. I., S. Yalcin, and P. D. Mulcahy. 1965. Alterations in aortic metabolism in diabetes. In On the Nature and Treatment of Diabetes. B. S. Leibel and G. A. Wrenshall, editors. Exerpta Medica Foundation, Publishers, Amsterdam. 452.

10. Travis, S. F., A. D. Morrison, R. S. Clements, Jr., A. I. Winegrad, and F. A. Oski. 1971. Metabolic alterations in the human erythrocyte produced by increases in glucose concentration. The role of the polyol pathway. J. Clin. Invest. 50: 2104.

11. Estabrook, R. W., J. R. Williamson, R. Frenkel, and P. K. Maitra. 1967. The fluorometric determination of mitochondrial adenine and pyridine nucleotides. Methods Enzymol. 10: 474.

12. Hohorst, H. J. 1963. L-(+)-Lactate. Determination with lactic dehydrogenase and DPN. In Methods of Enzymatic Analysis. H.-U. Bergmeyer, editor. VerlagChemie, Weinheim/Bergstr., Germany. 266.

13. Lowry, O. H., J. V. Passonneau, F. X. Hasselberger, and D. W. Schultz. 1964. Effect of ischemia on known substrates and cofactors of the glycolytic pathway in brain. J. Biol. Chem. 239: 18.

14. Lowry, O. H., N. J. Rosebrough, A. L. Farr, and R. J. Randall. 1951. Protein measurement with the Folin phenol reagent. J. Biol. Chem. 193: 265.

15. Sokal, R. R., and F. J. Rohlf. 1969. Biometry: The Principles and Practice of Statistics in Biological Research. W. H. Freeman and Co., San Francisco.

16. Hers, H. G. 1960. Le mécanisme de la formation du fructose séminal et du frctose foetal. Biochim. Biophys. Acta. $37: 127$.

17. Atkinson, D. E. 1971. Adenine nucleotides as stoichiometric coupling agents in metabolism and as regulatory modifiers: the adenylate energy charge. Metab. Pathways 1971. 5 : 1.

18. Klingenberg, M., and T. Bücher. 1960. Biological oxidations. Annu. Rev. Biochem. 29: 669.

19. Hayman, S., and J. H. Kinoshita. 1965. Isolation and properties of lens aldose reductase. J. Biol. Chem. 240: 877.

20. Clements, R. S., Jr., and A. I. Winegrad. 1969. Modulation of mammalian polyol: NADP oxidoreductase activity by ADP and ATP. Biochem. Biophys. Res. Commun. 36: 1006.

21. Smith, M. G. 1962. Polyol dehydrogenases. 4. Crystallization of the L-iditol dehydrogenase of sheep liver. Biochem. J. 83: 135.

22. Tobian, L., Jr., and L. White. 1956. The electrolytes of arterial wall in experimental renal hypertension. Circ. Res. 4 : 671.

23. Tobian, L., R. Olson, and G. Chesley. 1969. Water content of arteriolar wall in renovascular hypertension. Am. J. Physiol. 216: 22.

24. Whereat, A. F. 1967. Recent advances in experimental and molecular pathology. Atherosclerosis and metabolic disorder in the arterial wall. Exp. Mol. Pathol. 7: 233.

25. Haust, M. D. 1970. Injury and repair in the pathogenesis of atherosclerotic lesions. In Atherosclerosis: Proceedings of the 2nd International Symposium. R. J. Jones, editor. Springer-Verlag, Heidelberg. 12.

26. Robertson, A. L., Jr. 1968. Oxygen requirements of the human arterial intima in atherogenesis. Progr. Biochem. Pharmacol. 4: 305. 